\title{
V německých lesních školkách vládne rozmanitost a pohoda
}

Tereza Valkounová

Envigogika 10 (2) - Informace/ Information

Publikováno/Published dne 25. 4. 2015

DOI: $\underline{10.14712 / 18023061.478}$

\section{Abstrakt:}

Pedagogové lesních mateřských škol z celé České republiky vyrazili za kolegy do Berlína. Během jednoho lednového týdne navštívili pět lesních mateřských škol a centrum výzkumu pro děti Helleum.

\section{Abstract:}

Forest kindergarten teachers from around the Czech Republic spent a week in Berlin in January 2015 visiting their colleagues in five forest kindergartens and the Helleum Research Center for Children.

\section{Key words:}

Forest kindergartens, best practice examples 
V Berlíně fungují lesní školky přibližně od roku 2000. Třináct let fungující Waldwichtel je typickou lesní školkou, která funguje bez zázemí v budově.

„Je to klasická lesní mateřská školka - má maringotku na kraji městského lesa v blízkosti zastávky MHD. Funguje do oběda a navštěvuje ji patnáct dětí," přibližuje tuto

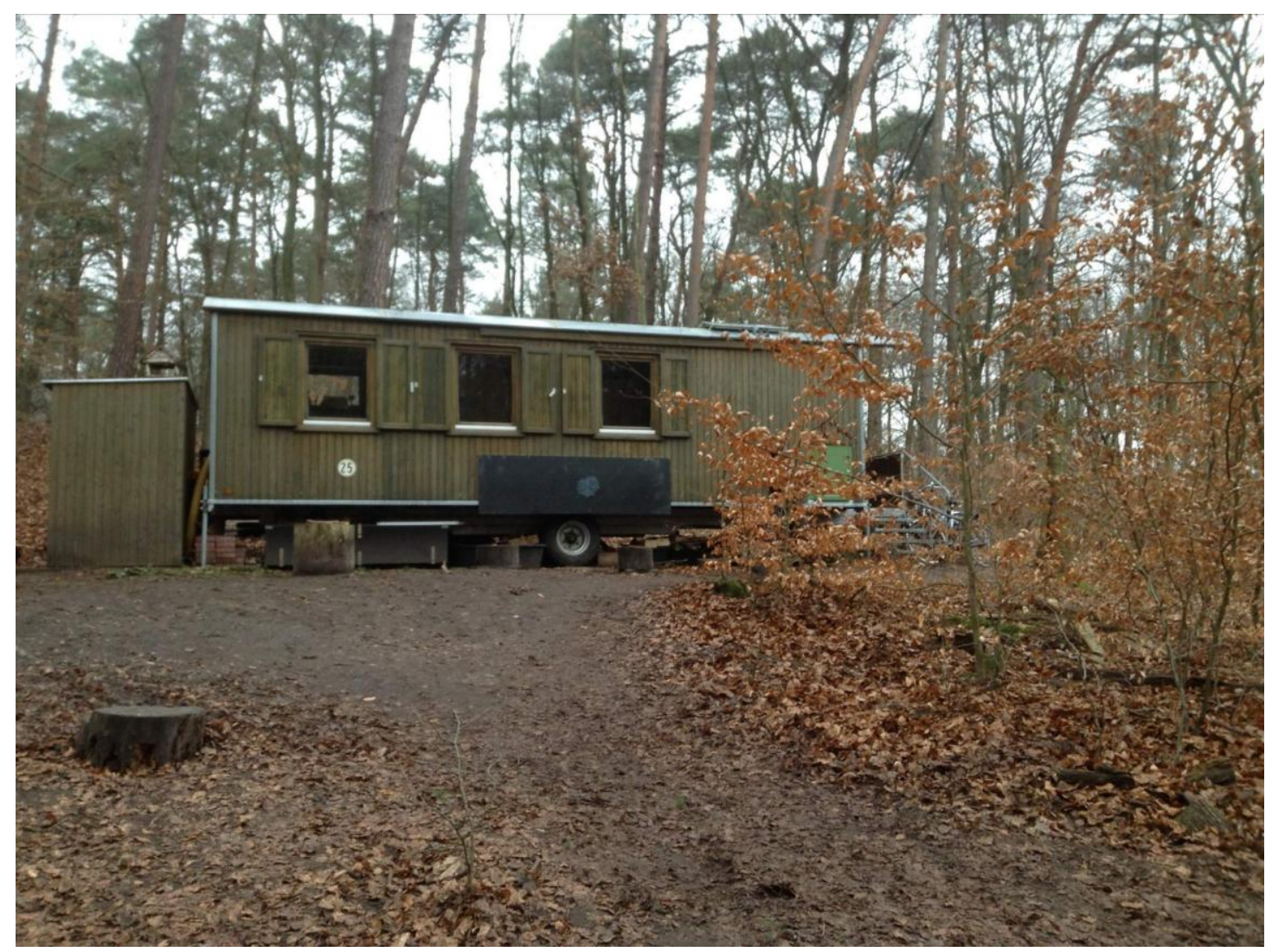

školku učitelka Angelika.

Př́kladem zařízení pro různé věkové skupiny dětí je organizace Baumhaus. Z pưvodní družiny pro školní děti se před několika lety rozrostla i o lesní mateřskou školku. „Družina je odpolední a prostory, které obec nově vybudovala podle našich potřeb, by byly dopoledne nevyužité. Družinu jsme už před tím vedli v duchu filosofie "venku za každého počasí, takže k lesní školce to byl už jen krůček," uvádí vedoucí lesní školky Gunter Grün Oostin-

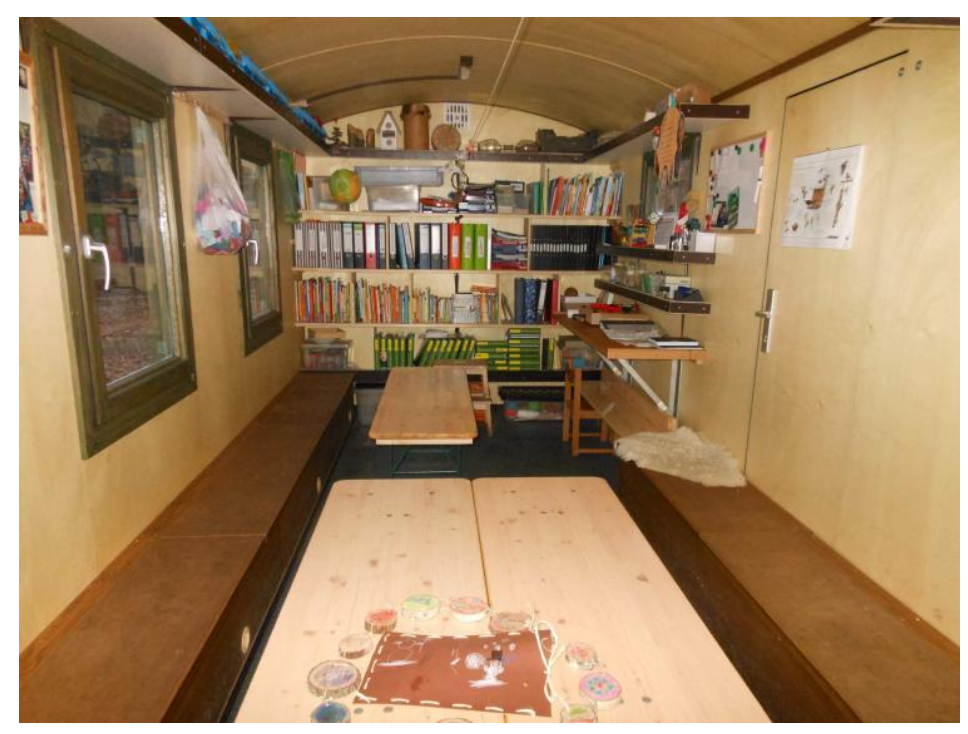


ga.

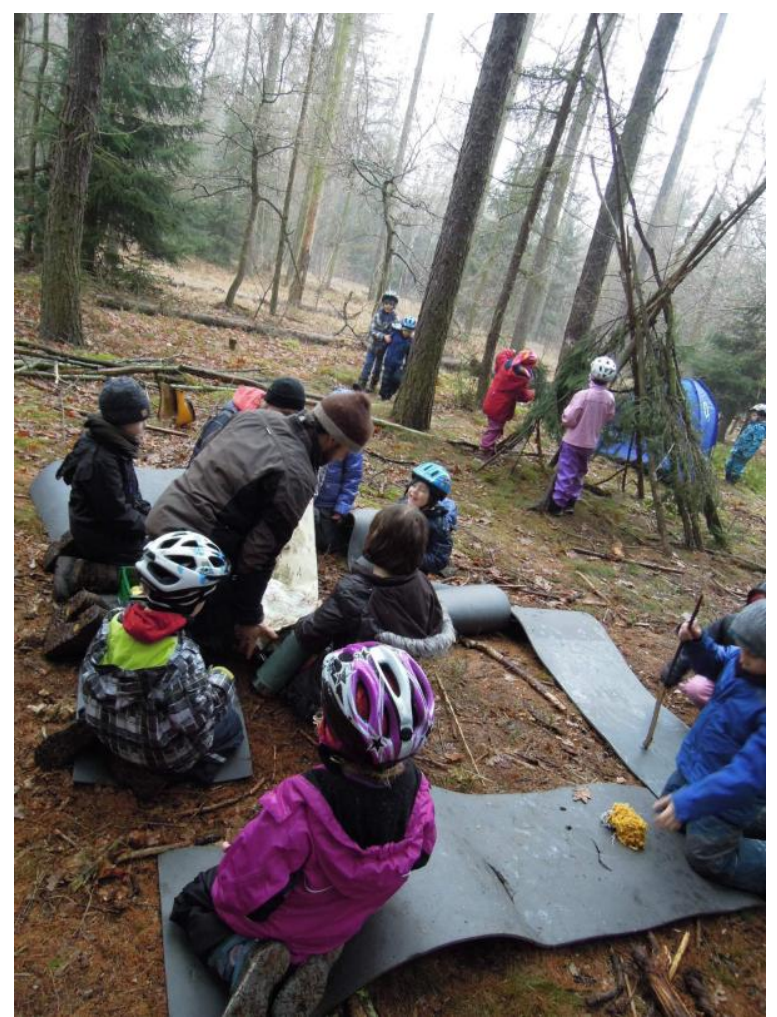

Českou skupinu tvořilo čtyřiadvacet budoucích Průvodců dětí světem, což je zároveň název rok a půl dlouhého vzdělávacího programu. Do německých lesních MŠ vyrazili, aby na vlastní kůži zažili fungování lesních školek v zimě. "Termín exkurze nebyl zvolen náhodou," ríká Tereza Valkounová z pořádající organizace Asociace lesních mateřských škol. "Otáz$k a$ 'jak to děláte $v$ zimě,' totiž patří $k$ nejčastějším k provozu lesní mateřské školy. Chceme také, aby se účastníci projektu vzdělávali co nejvíce z praxe, $v$ souladu $s$ principy vzdělávání pro udržitelný rozvoj." Projekt Průvodce dětí světem má podtitul Předškolní vzdělávání pro udržitelný rozvoj, což je výchozí vzdělávací koncept inspirovaný také $v$ Německu. Díky exkurzi měli účastníci možnost osobně se setkat $s$ jeho aplikací do praxe i ve vědeckovýzkumné instituci Helleum, která pořádá workshopy pro děti různého stáří zaměřené na témata vody, větru, zdroje energie atd.

„Těšíme se na společně strávený čas s ostatními společně studujícími a na inspiraci pro pobyt $s$ dětmi $v$ terénu. Také nás zajímá multikulturní prostředí, které u nás zatím tolik nemáme," sdělovali svá očekávání účastníci exkurze Ondřej Skalický a Zuzana Šubrtová cestou do Berlína.

Jak se jejich očekávání naplnila, reflektovali studenti každý večer $v$ rámci společného sdílení zážitků. $V$ rámci exkurze navštívili celkem šest institucí, které spojuje jedno: vzdělávat děti $v$ prímém kontaktu s prírodou a myšlenkou udržitelného rozvoje.

Kromě klasického Waldwichtelu navštívili další dvě typické lesní školky - Eichwalde aBergkinder. Setkali se s dětmi, které putují se svými průvodci

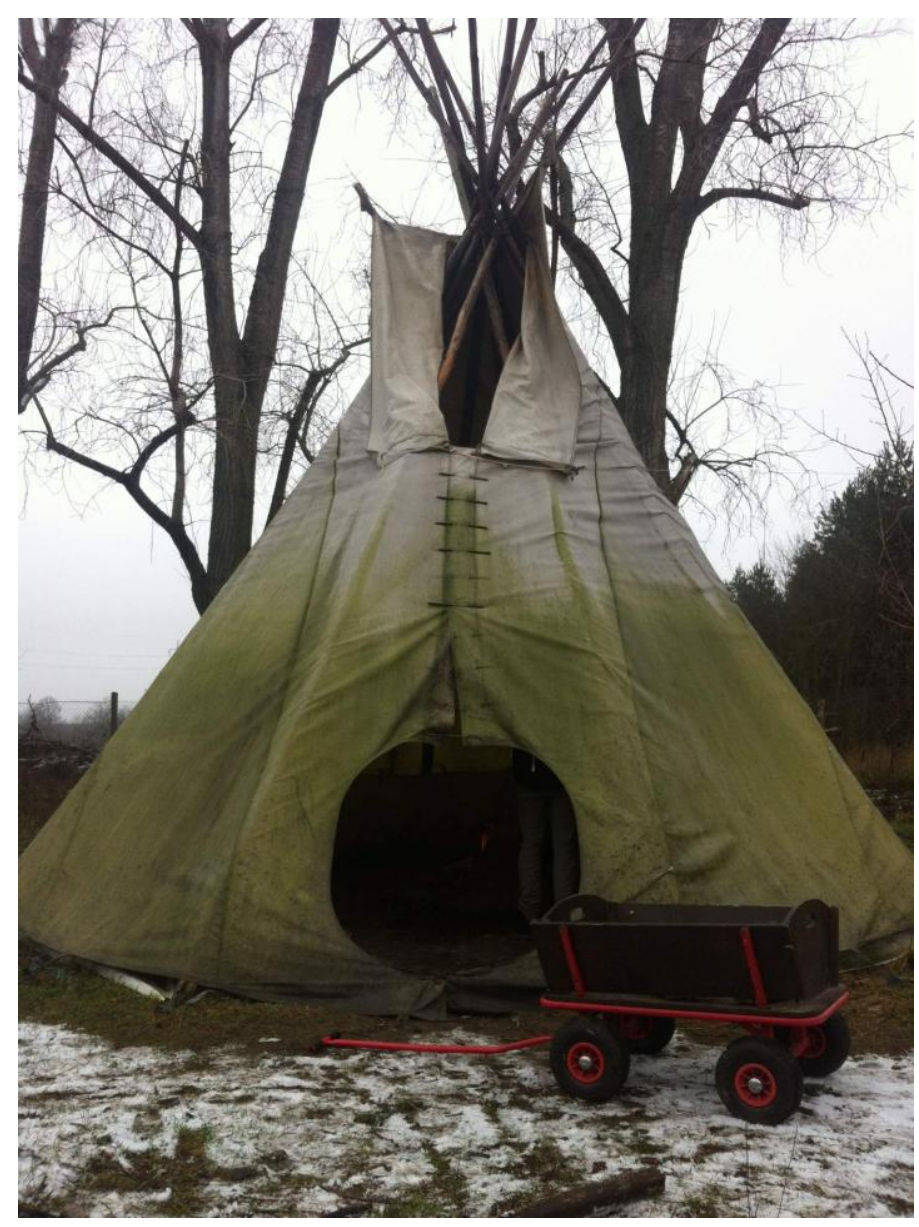




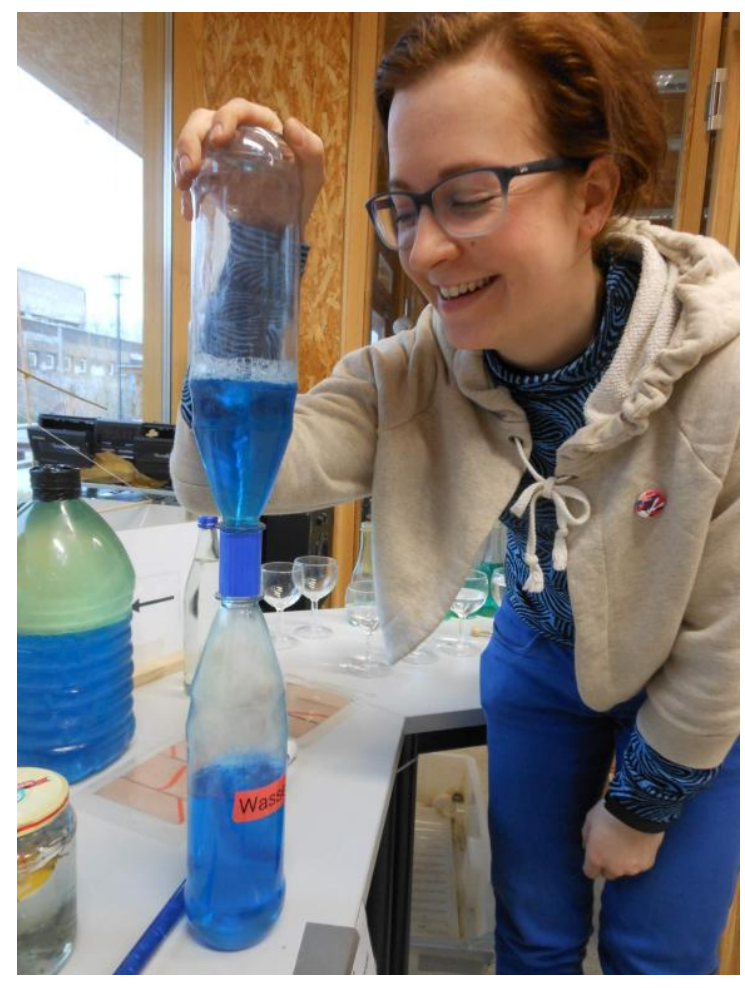

terénem, v batůžcích si nesou svačiny a teplý čaj a ve vozících veškeré vybavení: pilky, nožíky, náhradní oblečení, lékárničku, bandasku steplou vodou na mytí rukou, ale i pastelky, papíry, encyklopedie, atlasy a pohádkové knihy. Právě vášniví čtenáři v lese české učitelky a učitele př́jemně překvapily. "Kontakt s knížkami je důležitý mimo jiné pro rozvoj řeči," usmívá se učitelka Angelika z Waldwichtelu. Rozvoj řeči je jednou $z$ bedlivě sledovaných kompetencí předškolního vzdělávání v Německu.

Účastníci byli doslova nadšeni přístupem německých pedagogů $\mathrm{k}$ dětem. Pohoda a klid byly ve všech školkách pravidlem. "Na děti nikdo netlačí a nespěchá. Průvodci byli velmi laskaví a shovívaví! Měli pěkný přístup $v$ situaci, když se něco pokazí nebo nepovede. Věci jsou nahraditelné. Chyba nemá mít za následek, že se člověk příště činnosti neúčastní, neriskuje, aby zase nechyboval. To je příkladná práce s chybou. Učíme se cílem je cesta," shrnuje tuto zkušenost Dana Kafková, účastnice z Ústeckého kraje.

Profesionalita a laskavý respektující přístup byl pravidlem i ve výzkumném centru pro děti Helleum. Po krátkém úvodu následovaly dvě hodiny "volné hry" dětí v připraveném a do detailu promyšleném prostředí, které připomínalo výzkumnou laboratoř. Tématem byla právě voda. Děti mohly experimentovat a na základě vlastních zážitků, zkušeností a opakovaných pokusů dospět k nějakému poznání - at́ už o tom, co se stane s kapkou vody na rozpálené pánvičce, nebo zda banán, brambora či pomeranč plavou či se potopí.

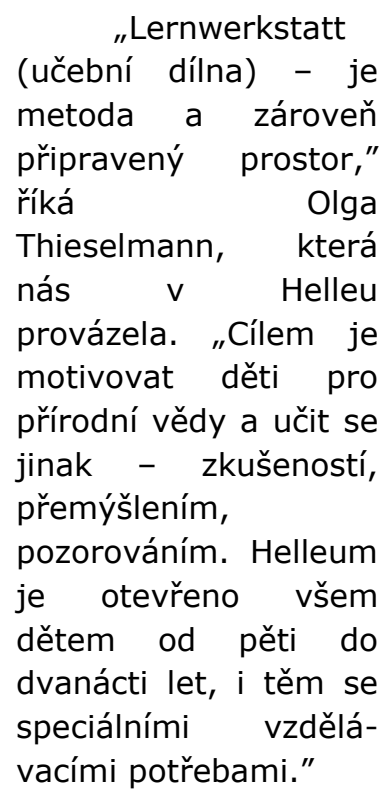

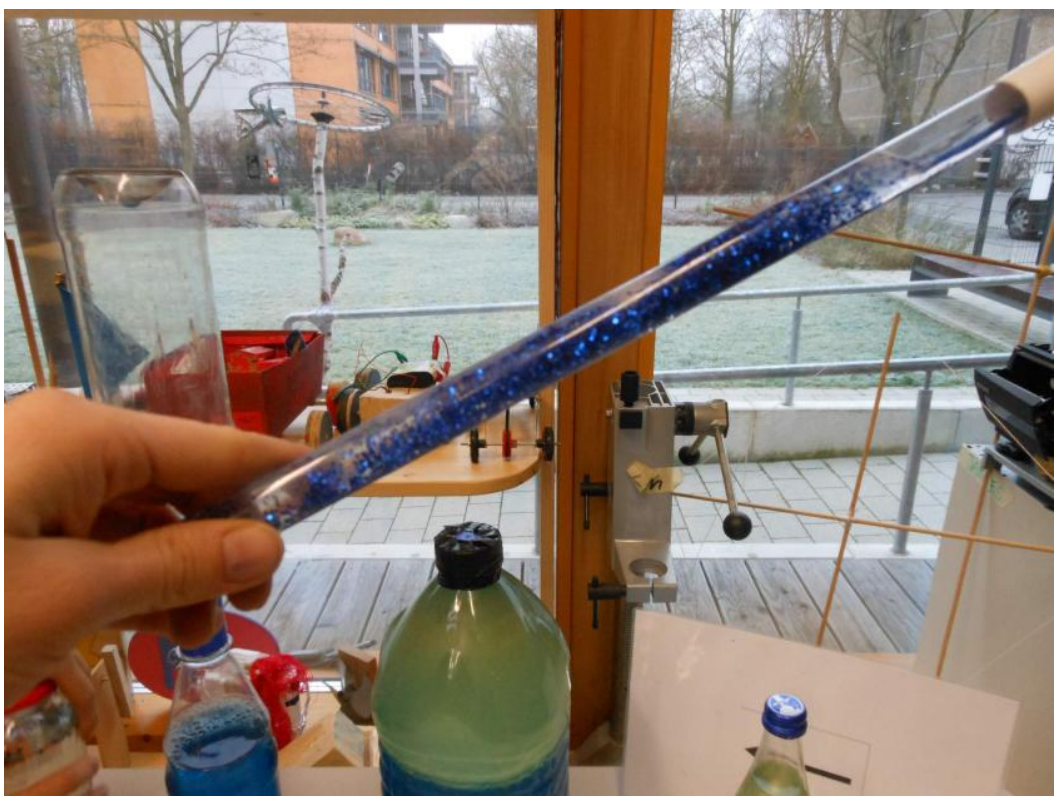




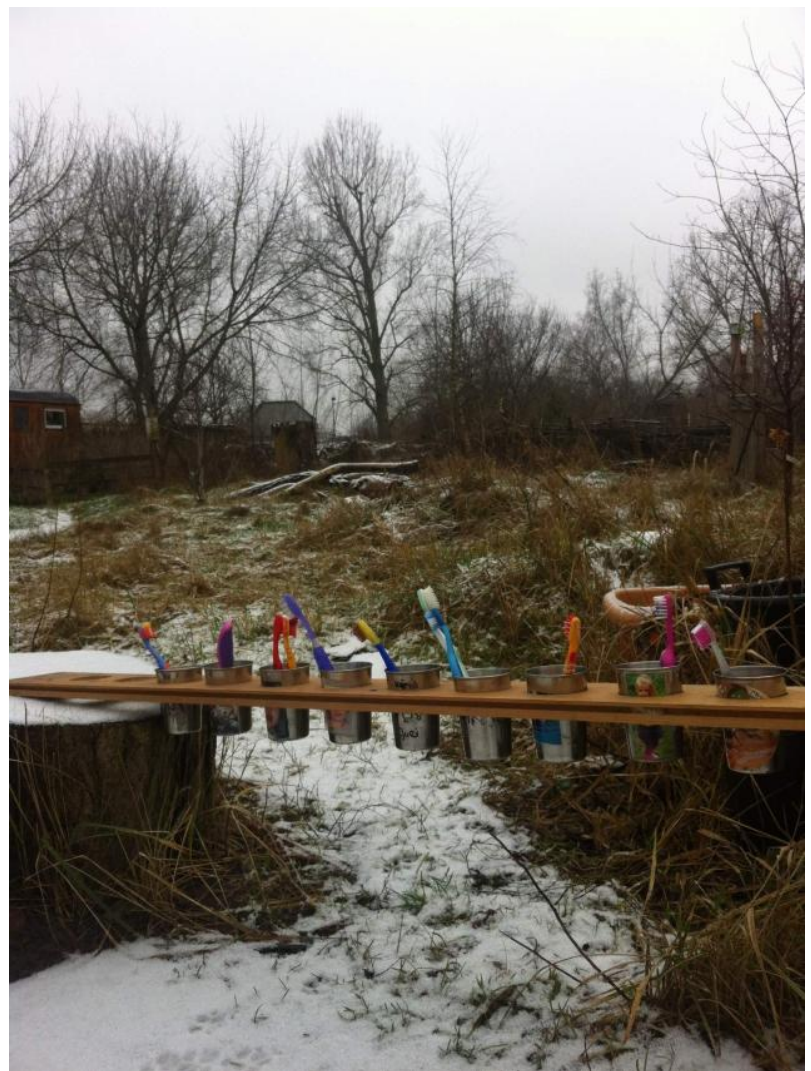

Dokladem rozmanitosti a různorodosti, která je $v$ něměckém vzdělávacím systému chápana jako předpoklad pro kvalitu předškolního vzdělávání, byla školka Kleine Pankgrafen, která již pět let funguje $v$ maringotkovém městečku. Školka se zázemím v maringotce a týpí je finančně podporována státem stejně, jako kterákoli jiná předškolní zařizení. Poskytuje péči nejen dětem z osady, ale i mnoha dalším z okolních čtvrtí. "Lesní školky jsou tady velice populární a žádané," usmívá se učitelka Maria. I tato školka, stejně jako všechny ostatní, považuje za samozrejmost inkluzi, tedy vzdělávání dětí se speciálními potřebami společně s těmi zdravými. Jeden z jejích kolegů si kvůli tomu doplňuje vzdělávání.

Předškolní vzdělávání v přímém kontaktu s prírodou v Německu by se dalo shrnout několika slovy: různorodost, pohoda, respekt, důvěra $v$ děti a $v$ rodiče, tolerance $k$ odlišnostem. Svět je pestrý a velký, každý si v něm najde své místo.

\section{ASOCIACE LESNÍCHMS}

Asociace lesních mateřských škol byla založena roku 2011. V současnosti sdružuje 120 organizací pečujících o 2500 dětí. Lesní školky vzdělávají děti v souladu s Rámcovým vzdělávacím programem stejně jako klasické MŠ. Přidanou hodnotou jsou lepší sociální vztahy díky menšímu kolektivu dětí, posilování obratnosti pohybem v terénu a posílení obranyschopnosti celoročním pobytem na čerstvém vzduchu. Pedagogický koncept lesních Mš je ve světě běžný již 100 let - v Norsku je integrovanou součástí celého vzdělávacího systému, v Německu je nyní 1500 lesních školek, které byly modelem pro Českou republiku.

Kontakt: Tereza Valkounová (tereza.valkounova@lesnims.cz, 777327227)

Projekt Předškolní vzdělávání pro udržitelný rozvoj, v jehož rámci se exkurze pedagogů předškolního vzdělávání do berlínských lesních MŠ uskutečnila, je podpořen grantem z Islandu, Lichtenštejnska a Norska v rámci EHP fondů. 
